Research Article

\title{
EVALUATION OF THE EFFICACY OF LEAF EXTRACT OF MANGIFERA INDICA+ROOT EXTRACT NAUCLEA LATIFOLIA IN LABORATORY RAT: TOWARDS THE CONTROL OF GASTRO INTESTINAL HELMINTHES INFECTION
}

\author{
Mohammed A Rufai ${ }^{1 *}$ and Akeem Akinboro ${ }^{2}$
}

${ }^{1}$ Department of Zoology, College of Science, Engineering and Technology, Osun State University, Osogbo, Nigeria ${ }^{2}$ Department of Pure and Applied Biology, Ladoke Akintola University (LAUTECH), Ogbomosho, Nigeria

Article History: Received 17 $7^{\text {th }}$ June, 2019; Accepted 24 June, 2019; Published 30 ${ }^{\text {th }}$ June, 2019

\begin{abstract}
There are a large number of plants whose anthelmintic activity has been demonstrated under controlled experimentation, either through feeding the whole plant or administering plant extracts to parasitised hosts. However, contrary to traditional expectation, there are also a great number of plants with purported antiparasitic properties, which have not been reproduced under experimental conditions. Studies on the helminthicidal activities of leaf extract of Mangifera indica+root extract of Nauclea latifolia in mice was designed to determine their efficacies against intestinal helmithes. Sixty Swiss albino mice maintained conventionally were selected randomly from laboratory animal house. The collected faecal samples were examined by simple faecal flotation techniques for isolation of parasitic eggs and/or oocysts. $42(70.0 \%)$ of the mice under study were infected with at least one gastro intestinal parasite. The leaf extract of Mangifera indica+root extract of Nauclea latifolia was prepared by boiling in tap water. Graded concentrations $(100 \%, 50 \%, 25 \%$ and $12.5 \%)$ of stock that was produce in Tetfund Zoology Laboratory of Osun State University was tested against both mice of different weights and sexes for helminthicidal efficacy. LC50 of the extract value obtained was found to be $75 \mathrm{mg} / \mathrm{l}$ in both big and small mice. Prevalence of gastrointestinal infections reduced with increased concentration of extract. Statistical analysis using analysis of variance indicated that there was a significant difference in the means of the treatment concentrations and the rates of prevalence of gastrointestinal infections in the sampled mice. The results of this research showed that the leaf extract of Mangifera indica+root extract of Nauclea latifolia are highly active against intestinal helminths in the sampled mice. The extract action also had significant influence ( $p>0.05$ ) on the time of exposure of mice and the rate of prevalence. The safety of the leaf extract of Mangifera indica+root extract of Nauclea latifolia on vital organs of humans may need to be investigated to determine its safety on humans.
\end{abstract}

Keywords: Efficacy; Root extracts; Mangifera indica; Nauclea latifolia; Swiss albino mice; Gastro intestinal parasitic parasites

\section{INTRODUCTION}

Intestinal tract parasites cause significant morbidity and mortality throughout the world, particularly in undeveloped countries where there is limited access to safe drinking water, sanitation, and nutrition (Anosike et al., 2006). They are widely distributed throughout the world causing substantial implication to the public health, economy, and physical and cognitive development particularly among children in developing countries like Nigeria. The poor personal hygiene, poor environmental hygiene, and poor health system commonly observed in developing countries make the prevalence to be highest among these populations (PAHO, 2011).

Intestinal parasites are most prevalent in children of schoolgoing-age, pregnant women and immune-compromised individuals (Anosike et al., 2006). Children with parasite infections may suffer from a wide variety of symptoms including anaemia as well as a myriad of mental and physical problems (Rufai and Awi - Waadu, 2006). As intestinal parasites survive by removing important nutrition from their human host, children infected with gastrointestinal parasites may have decreased mental and physical development. Thus the parasitic disease may have far greater effects than are immediately apparent and may decrease the learning ability and productivity of infected children. Intestinal parasite infestation in pregnant women is also of particular concern. It may result in anaemia, a weakened immune system and a resulting susceptibility to infections, all of which may affect foetal survival and development (Tsoka-Gwegweni and Ntombela, 2014). Maternal intestinal parasite infestation may result in low birth-weight infants who are also susceptible to infections and have developmental problems. Even postnatal, maternal infestation may cause lethargy and malaise which may adversely affect the mothers' ability to provide adequate care for the infant.

Studies have established that some types of worm are in the intestines of over 75 percent of the world's population'. This is a frightening statement. Common intestinal parasites include: 
Roundworm (Ascaris lumbricoides), Hookworm (Necator americanus, Ancylostoma duodenal), Pinworm (Enterobius vermicularis), Roundworm (Toxocara canis, Toxocara cati), Heart worm (Dirofilaria immitis), Strongyloides (Stronglyoides stercoralis), Trichinella (Trichinella spiralis) (Mehmet and Oprah, 2015).

The main drugs used to treat human intestinal parasites nowadays are mebendazole, albendazole, pyrantel pamoate, and levamisole for intestinal nematodes, ivermectin (IVM) for onchocerciasis, and DEC alone or DEC-albendazole and IVM-albendazole combination treatments for filariasis (Albonico et al., 1999). Depending on local epidemiology, availability, and cost, these drugs have been widely available in most health care systems for the curative treatment of clinical cases for many years.

In recent years, several reports of apparent failures in the treatment of intestinal parasites and nematodes have been published (De Clercq et al., 1997, Ismail et al., 1996). These have led to an increased awareness of the potential problem of anthelmintic resistance in the treatment and control of human helminths.

Even multiple drug resistance is not uncommon in helminths of veterinary importance. In parts of Paraguay (Maciel et al., 1999), helminths are resistant to all available broadspectrum anthelmintics and farmers have started to give up sheep farming because of insurmountable problems with anthelmintic resistance (Reynoldson et al., 1997).

Because vaccinations do not work in most instances and the parasites have sometimes become resistant to the available synthetic therapeutics, it is important to search for alternative sources of anti-parasitic drugs. Plants produce a high diversity of secondary metabolites with interesting biological activities, such as cytotoxic, anti-parasitic and anti-microbial properties. These drugs often interfere with central targets in parasites, such as DNA (intercalation, alkylation), membrane integrity, microtubules and neuronal signal transduction. Plant extracts and isolated secondary metabolites which can inhibit protozoan parasites, such as Plasmodium, Trypanosoma, Leishmania, Trichomonas and intestinal worms are discussed. The identified plants and compounds offer a chance to develop new drugs against parasitic diseases. Most of them need to be tested in more detail, especially in animal models and if successful, in clinical trials.

Despite the number of plants with recorded ethnobotanical uses against gastrointestinal worms and helminths, no rigorous studies have yet evaluated the activity of most medicinal plants against specific human intestinal worms. Instead, previous research has relied on the use of model organisms as a substitute for these parasites. Most studies have used the free living (non-parasitic) nematode Caenorhabditis elegans as a helminth model to represent human intestinal worms. Acorus calamus, Cotyledon orbiculatavar orbiculata, Cyathea dregei, Melia azedarach and Tulbaghia violacea have all been reported to have activity against $C$. elegans (Aremu et al., 2012). There are also a large number of plants whose anthelmintic activity has been demonstrated under controlled experimentation, either through feeding the whole plant or administering plant extracts to parasitised hosts. However, contrary to traditional expectation, there are also a great number of plants with purported antiparasitic properties, which have not been reproduced under experimental conditions (Ahmed et al., 2013; Adenubi et al., 2016; Aremu, 2009).

Leaves of Nauclea latifolia and roots of Mangifera indica are both important medicinal plants which plays an important role in management of many pathological conditions in developing countries of the world.

This work therefore studies the helminthicidal activities of leaf extract of Mangifera indica+root extract Nauclea latifolia in mice for the control of intestinal helminthes infections owing to the increasing toxicity and resistance to hitherto widely used parasitic infections' drugs.

\section{MATERIALS AND METHODS}

\section{Preparation of stock solution and various concentrations of leaf extract of Mangifera indica+Root extract of Nauclea latifolia used}

$100 \mathrm{~g}$ of plant root of Nauclea latifolia and $100 \mathrm{~g}$ plant leaf of Mangifera indica were weighed and boiled in 2 litres of clean tap water for thirty (30) minutes and allowed to cool. This was freeze dried in freeze dryer machine to turn the liquid recipe into powdery form (Behnke et al., 2001, Adenubi et al., 2016, Ahmed et al., 2013). The powder was placed in universal bottles containing $10 \mathrm{ml}$ sterile distilled water after which they were filtered into a conical flask using a filter paper and a funnel to produce a clear juice. From this mixture of leaf extract of Mangifera indica+root extract of Nauclea latifolia, a stock solution was made in universal bottles by adding $0.1 \mathrm{ml}$ of the mixture to $9.9 \mathrm{ml}$ of sterile distilled water followed by agitation for one minute. From the stock solution $100 \mathrm{mg} / 1,50 \mathrm{mg} / 1,25 \mathrm{mg} / 1,12.5 \mathrm{mg} / 1$ dilutions were prepared by fetching $1 \mathrm{ml}, 0.5 \mathrm{ml}, 0.25 \mathrm{ml}$, and $0.125 \mathrm{ml}$ and added to six beakers each containing $100 \mathrm{ml}$ of water (Table 1). All concentrations were prepared in duplicates. A control beaker was set up having only water (Aremu et al., 2009, Rufai et al., 2017).

\section{Testing for prevalence of gastro-intestinal parasites in laboratory animals}

A total of sixty (60) Swiss albino mice weighing between 105-158 g maintained conventionally were selected randomly from laboratory animal house. The (60) Swiss albino mice were divided into a group of five, resulting in 5 groups labelled G0, G1, G2, G3 and G4. The faeces of each group of mice were collected and examined by parasitological methods for the presence of intestinal parasites before extract was fed to them and prevalence and intensities were noted. The animals were housed and bred in the well-ventilated wooden cages with metal wiring and were fed once daily with commercially formulated rat feed and water was given 
ad libitum. The research was carried out in accordance with the ethical rules on animals experimentation approved by the ethical committee of Osun State University.

\section{Testing for helminthicidal efficacy of leaf extract of Mangifera indica+root extract of Nauclea latifolia}

Four of the groups of the mice $(\mathrm{G} 1, \mathrm{G} 2, \mathrm{G} 3$ and G4) were each treated with $100 \mathrm{mg} / 1,50 \mathrm{mg} / 1,25 \mathrm{mg} / \mathrm{l}$ and $12.5 \mathrm{mg} / \mathrm{l}$ of extract except G0 group that was not treated but were given $1 \mathrm{ml}$ of distilled water and serve as the control. After one week of extract application, the faeces of the mice were again collected and examined by parasitological methods. After five days, the prevalence and intensity of gastro-intestinal helminthes among the sampled groups was obtained. The recovered helminthes were examined and counted using the compound microscope. Morphological identification was done using perineal patterns for species identification as described by Bundy et al (1998).

\section{RESULTS}

The prevalence and intensities of gastrointestinal helminthes parasites in the sixty (60) Swiss albino mice prior to administration of various concentrations of leaf extract of Mangifera indica+root extract of Nauclea latifolia against helminthes is given in Table $1.42(70.0 \%)$ of the mice under study had parasitic infection with at least one parasite. Seven genera of parasites were detected in the mice, the three of which were protozoa including Entamoeba muris, Eimeria spp. and Cryptosporidium spp., and the four other ones were helminths including Hymenolepis nana, Hymenolepis diminuta, Syphacia muris and Strongyloides ratti. E. muris showed the highest prevalence rate $(96 \%)$ followed by $S$. ratti $(95 \%)$. The lowest prevalence rate was observed in infections with Hymenolepis diminuta and Syphacia muris, all with $2.5 \%$ and $2.3 \%$ prevalence respectively. Polyparasitic contamination was observed in the sampled mice. 27 (11.7\%) of the total samples were contaminated with two species of parasites, while $8(13.3 \%)$ of the samples with three species of parasites and single parasitic contamination were observed 7 (11.7\%) (Table 2).

The prevalence of intestinal helminthes parasites in the sampled population in relation to sex of the mice showed that female had higher prevalence rate $25(41.7 \%)$ than male with $17(28.3 \%)$. Percentage infection rates showed that there was statistically significant association between the sexes and prevalence rate. Age specific prevalence of parasites showed that adult mice had the highest prevalence of 29 (48.3\%), while the young mice had the least with $13(21.7 \%)$ out of 42 (70.0\%) infected (Table 2).

Table 2 showed the result of the antihelminthic activities of various concentrations of the leaf extract of Mangifera indica+root extract of Nauclea latifolia against gastrointestinal parasites in the sampled mice. Treatment was observed for 5 days after which prevalence rate was determined. Prevalence rate was seen to have reduced from treatments with higher concentrations to lower concentrations. The highest concentrations of $100 \mathrm{mg} / 1$ and $50 \mathrm{mg} / \mathrm{l}$ were recorded to have reduced the prevalence rate in $\mathrm{G} 3$ from $8(66.7 \%)$ to $0(0 \%)$ and $\mathrm{G} 4,9(75.0 \%)$ to $0(0 \%)$ while the prevalence in $\mathrm{G} 0$ was found to have increased from $8(66.7 \%)$ to $10(83.3 \%)$ (Tables 2 and 3$)$. The intensities of gastrointestinal helminthes in the sampled mice before and after treatment recorded reduction in the intensities of all the parasites (Tables 4 and 5). Statistical analysis using analysis of variance indicated that there was a significant difference in the means of the treatment concentrations and the rates of prevalence of gastrointestinal infections in the sample mice.

Table 1: Various concentrations of leaf extract of Mangifera indica + root extract of Nauclea latifolia used.

\begin{tabular}{|c|c|c|c|c|c|}
\hline & \multicolumn{7}{|c|}{ Weight(mg) of the extract (stock solution) per volume of different concentrations } & Solution 5 \\
\hline Solution & Solution 1 & Solution 2 & Solution 3 & Solution 4 & 0 \\
\hline Stock solution & 1 & 0.5 & 0.25 & 0.125 & 0 \\
\hline $10 \mathrm{ml}$ & $100 \mathrm{mg} / 1$ & $50 \mathrm{mg} / 1$ & $25 \mathrm{mg} / 1$ & $12.5 \mathrm{mg} / 1$ & 0 \\
\hline
\end{tabular}

Table 2: The prevalence of intestinal helminthes in the sampled mice before treatment with leaf extract of Mangifera indica+root extract of Nauclea latifolia.

\begin{tabular}{|c|c|c|c|c|c|}
\hline \multirow{2}{*}{ Variable } & \multirow{2}{*}{ No of rats examined } & \multirow{2}{*}{ No $(\%)$ infected } & \multicolumn{3}{|c|}{ Number of parasitic spp } \\
\hline & & & One (\%) & Two (\%) & Three (\%) \\
\hline \multicolumn{6}{|c|}{ Group (G) } \\
\hline G1 & 12 & $7(58.3)$ & $1(8.3)$ & $5(41.7)$ & $1(8.3 \%)$ \\
\hline $\mathrm{G} 2$ & 12 & $10(83.3)$ & $2(16.7)$ & $7(58.3)$ & $1(8.3 \%)$ \\
\hline G3 & 12 & $8(66.7)$ & $2(16.7)$ & $4(33.3)$ & $2(16.7 \%)$ \\
\hline G4 & 12 & $9(75.0)$ & $1(8.3)$ & $6(50.0)$ & $2(16.7 \%)$ \\
\hline \multicolumn{6}{|c|}{ Sex } \\
\hline Male & 34 & $17(28.3)$ & $4(11.8)$ & $10(29.4 \%)$ & $3(8.8 \%)$ \\
\hline Female & 26 & $25(41.7)$ & $3(11.5)$ & $17(65.4 \%)$ & $5(19.2 \%)$ \\
\hline \multicolumn{6}{|c|}{ Age } \\
\hline Young & 30 & $13(21.7)$ & $2(6.7)$ & $8(26.7 \%)$ & $3(10.0 \%)$ \\
\hline Overall & 60 & $42(70.0)$ & $7(11.7)$ & $27(45.0 \%)$ & $8(13.3 \%)$ \\
\hline
\end{tabular}


Table 3: The prevalence of intestinal helminths in the sampled mice after treatment with leaf extract of Mangifera indica+root extract of Nauclea latifolia.

\begin{tabular}{|c|c|c|c|c|c|}
\hline \multirow{2}{*}{ Variable } & \multirow{2}{*}{ No of rats examined } & \multirow{2}{*}{ No (\%) infected } & \multicolumn{3}{|c|}{ Number of parasitic spp } \\
\hline & & & One $(\%)$ & Two (\%) & Three (\%) \\
\hline \multicolumn{6}{|c|}{ Group (G) } \\
\hline G0 & 12 & $10(66.7 \%)$ & $2(8.3 \%)$ & 6 & 2 \\
\hline G1 & 12 & 7 & 1 & 5 & 1 \\
\hline $\mathrm{G} 2$ & 12 & 3 & 0 & 2 & 1 \\
\hline G3 & 12 & 0 & 0 & 0 & 0 \\
\hline G4 & 12 & 0 & 0 & 0 & 0 \\
\hline \multicolumn{6}{|c|}{ Sex } \\
\hline Male & 34 & 7 & 2 & 5 & $1(8 \%)$ \\
\hline Female & 26 & 13 & 1 & 8 & 3 \\
\hline \multicolumn{6}{|c|}{ Age } \\
\hline Young & 30 & 2 & 0 & 2 & 0 \\
\hline Adult & 30 & 18 & 3 & 11 & 4 \\
\hline Overall & 60 & 20 & 3 & 13 & 4 \\
\hline
\end{tabular}

Table 4: The intensities of intestinal helminthes in the sampled mice before and after treatment with leaf extract of Mangifera indica+root extract of Nauclea latifolia.

\begin{tabular}{|c|c|c|}
\hline \multirow{2}{*}{ Parasites } & \multicolumn{2}{|c|}{ Mean of the ova/cysts of the parasite per mice } \\
\cline { 2 - 3 } & Before Treatment & After Treatment \\
\hline Hymenolepis diminuta & 4 & 1.5 \\
\hline Hymenolepis nana & 3.5 & 0.5 \\
\hline Syphacia muris & 3.4 & 1.5 \\
\hline Strongyloides ratti & 7.3 & 0 \\
\hline Entamoeba muris & 10.7 & 0 \\
\hline Cryptosporidium spp. & 9.3 & 0 \\
\hline Eimeria spp. & 12.7 & 0 \\
\hline
\end{tabular}

Table 5: Sample diagnostic doses and diagnostic times for the prevalence of intestinal helminths.

\begin{tabular}{|c|c|c|c|c|c|c|}
\hline \multirow{2}{*}{$\begin{array}{c}\text { Extract } \\
\text { concentrations }\end{array}$} & \multicolumn{5}{|c|}{ Prevalence of intestinal parasites per group } & \multirow{2}{*}{$\begin{array}{c}\text { Diagnostic time } \\
\text { (days) }\end{array}$} \\
\hline & G0 & $\mathrm{G} 2$ & $\mathrm{G} 3$ & G4 & G5 & \\
\hline $0 \mathrm{mg} / \mathrm{l}$ & $8(66.7 \%)$ & $7(58.3 \%)$ & $10(83.3 \%)$ & $8(66.7 \%)$ & $9(75.0 \%)$ & 5 \\
\hline $12.5 \mathrm{mg} / 1$ & $7(58.3 \%)$ & $7(58.3 \%)$ & $7(58.3 \%)$ & $7(58.3 \%)$ & $7(58.3 \%)$ & 5 \\
\hline $25 \mathrm{mg} / 1$ & $3(25.0 \%)$ & $3(25.0 \%)$ & $3(25.0 \%)$ & $3(25.0 \%)$ & $3(25.0 \%)$ & 5 \\
\hline $50 \mathrm{mg} / 1$ & $0(0 \%)$ & $0(0 \%)$ & $0(0 \%)$ & $0(0 \%)$ & $0(0 \%)$ & 5 \\
\hline $100 \mathrm{mg} / 1$ & $0(0 \%)$ & $0(0 \%)$ & $0(0 \%)$ & $0(0 \%)$ & $0(0 \%)$ & 5 \\
\hline
\end{tabular}

The results of this research showed that the leaf extract of Mangifera indica+root extract of Nauclea latifolia is highly active against intestinal helminths in the sampled mice.

\section{DISCUSSION AND CONCLUSION}

Table 4 shows the influence of leaf extract of Mangifera indica+root extract of Nauclea latifolia treatment levels on the prevalence and intensities of gastrointestinal helminthes in the sampled mice. After 5 days after treatments (5DAT), the data revealed that $\mathrm{G} 0$ recorded increase in the prevalence of gastrointestinal helminthes after treatment (Table 4). This may be attributed to growth in the number of parasites due to no hindrance. Prevalence in G1, G2, G3 and G4 reduced consistently with various concentrations with zero prevalence of helminthes recorded in G3 and G4 (Table 4). This can be attributed to the antihelmintic activities of the leaf extract of Mangifera indica+root extract of Nauclea latifolia treatment. Helminthes mortality was recorded to increase gradually from lower concentrations to higher concentrations. The lowest prevalence and intensities of parasites were recorded at $50 \mathrm{mg} / \mathrm{l}$ and $100 \mathrm{mg} / \mathrm{l}$ concentrations and $50 \mathrm{mg} / \mathrm{l}$ as the lethal concentration (LC50) determined from the sample diagnostic doses and diagnostic times for the prevalence of gastrointestinal parasites (Table 5). Statistical analysis using analysis of variance indicated that there was a significant difference in the means of the treatment concentrations and the rates of prevalence of gastrointestinal infections in the sampled mice. The results of this research showed that the leaf extract of Mangifera indica+root extract of Nauclea latifolia are highly active against gastrointestinal parasites in the sampled mice. The extract action also had significant influence $(p>0.05)$ on the time of exposure of mice and the rate of prevalence (Table 5).

The results of this work showed that leaf extract of Mangifera indica+root extract of Nauclea latifolia is highly active against gastrointestinal helminthes infection. Although there had been practice in some part of the world where leaf extract of Mangifera indica+root extract of Nauclea latifolia was 
used locally against malarial infection, its efficacy against gastrointestinal helminth parasites that was discovered in this study is recommended for the control of gastro-helminth parasites.

\section{CONFLICT OF INTERESTS}

The authors declare that there is no conflict of interests regarding the publication of this paper.

\section{AUTHORS' CONTRIBUTION}

Rufai Mohammed conceived the study, participated in the study design, data collection, data analysis, and drafted the paper for publication. Akeem Akinboro participated in study design sample collection, laboratory wok, data analysis and interpretation. All authors have read and approved the final copy

\section{ACKNOWLEDGEMENT}

The author appreciates the assistance of the technical staff of Zoology laboratory of Osun State University for their cooperation during this study.

\section{REFERENCES}

1. Anosike, J. C., Zaccheaus, V. O., Adeiyongo, C. M., Abanobi, O. C., Dada, E. O., Oku, E. E., Keke, I. R., Uwaezuoke, J. C., Amajuoyi, O. U., Obiukwu, C. E., Nwosu, D. C., and Ogbusu, F., (2016). I. Studies on the Intestinal Worm (Helminthiasis) Infection in a Central Nigerian Rural Community. JASEM., 10: 61-66.

2. Pan American Health., 2011. Organization/World Health Organization (PAHO/WHO). The publication Health Situation in the Americas.

3. Rufai, A. M., and Awi Waadu, G. D. B., (2006). Prevalence of Human Gastro-intestinal parasitic infections in relation to Human and Industrial activities in Rumuolumeni community in Rivers State, Nigeria. AJAZEB., 8; 62-66.

4. Tsoka-Gwegweni, J. M., Ntombela, N. P., (2014). A Double Load to Carry: Parasites and Pregnancy. South. Afr. J. Infect. Dis., 29: 52-55.

5. Albonico, M., Crompton, D. W. T., and Savioli, L., (1999). Control strategies for human intestinal nematode infections. Adv. Parasitol., 1999; 42: 277-341.

6. De Clercq, D., Sacko, M., Behnke, J., Gilbert, F., Dorny, P., and Vercruysse, J., (1997). Failure of mebendazole in treatment of human hookworm infections in the southern region of Mali. Am. J. Trop. Med. Hyg., 57: 25-30.

7. Ismail, M., Metwally, A., Farghaly, A., Bruce, J., Tao, L. F., and Bennett, J. L., (1996). Characterization of isolates of Schistosoma mansoni from Egyptian villagers that tolerate high doses of praziquantel. Am. J. Trop. Med. Hyg., 55: 214-218.

8. Maciel, S., Gimenez, A. M., Gaona, C., Waller, P. J., and Hansen J. W., (1996). The prevalence of anthelmintic resistance in nematode parasites of sheep in Southern Latin America: Paraguay. Vet. Parasitol., 62: 207-212.

9. Reynoldson, J. A., Behnke, J. M., Pallant, L. J., Macnish, M. G., Gilbert, F., Giles, S., Spargo, R. J., and Thompson, R. C. A., (1997). Failure of pyrantel in treatment of human hookworm infections (Ancylostoma duodenale) in the Kimberley region of North West Australia. Acta. Trop., 68: 301-312.

10. Aremu, A.O., Finnie, J.F., and Van Staden, J., (2012). Potential of South African medicinal plants used as anthelmintics. Their efficacy, safety concerns and reappraisal of current screening methods. S. Afr. J. Bot., 82: 134-150.

11. Bundy, D. A., and De Silva, N. R., (1998). Can we deworm this wormy world? Br. Med. Bull., 54:421-432.

12. Behnke, J. M., Bajer, A., Sinski, E., and Wakelin, D., (2001). Interactions involving intestinal nematodes of rodents: experimental and field studies. Parasitol., 122: 39-49.

13. Adenubi, O. T., Fasina, F. O., McGaw, L.J., Eloff, J.N., and Naido, V., (2016). Plant extracts to control ticks of veterinary and medical importance: a review. S. Afr. J. Bot., 105: 178-193.

14. Ahmed, A.S., McGaw, L.J., and Eloff, J., (2013). Evaluation of pharmacological activities, cytotoxicity and phenolic composition of four Maytenus species used in southern African traditional medicine to treat intestinal infections and diarrhoeal diseases. BMC Complement. Altern. Med., 13: 1-15.

15. Aremu, A. O., (2009). Pharmacology and Phytochemistry of South African Plants used asAnthelmintics (Master of Science). University of KwaZulu-Natal., Pietermaritzburg.

16. Rufai, A. M., and Olagunju, R.O., (2017). Implication of Rattus rattus as Vectors of Gastrointestinal helminthes Parasites in Parts of Osogbo, Southwestern Nigeria. $J$ Advanced Botany and Zoology., V5I1. 